\title{
Effect of heat treatment on the tribological properties of Nickel-Boron electroless coating
}

\author{
Efecto del tratamiento térmico sobre las propiedades tribológicas del \\ recubrimiento autocatalítico níquel-boro
}

Efeito do tratamento térmico sobre as propriedades tribológicas do
recobrimento autocatalítico níquel-boro

Fecha de recepción: 1 de agosto de 2017

Fecha de aprobación: 4 de diciembre de 2017

\author{
Sandra Arias* \\ Maryory Gómez* \\ Esteban Correa ${ }^{*+*}$ \\ Félix Echeverría-Echeverría \\ Juan Guillermo Castaño"
}

\section{Abstract}

Nickel-Boron autocatalytic coatings are widely used in several industries to improve mechanical properties of materials such as hardness and wear resistance. Tribological properties were evaluated in Ni-B autocatalytic coatings deposited on AISI/SAE 1018 carbon steel before and after a heat treatment at $450{ }^{\circ} \mathrm{C}$ for one hour. Tribological tests were carried out by dry sliding, using a load of $5 \mathrm{~N}$ and a sliding speed of $0.012 \mathrm{~m} / \mathrm{s}$, in a homemade ball-on-disk tribometer, which followed ASTM G99 standard. According to the tribological evaluation, the heat treatments applied to Ni-B coatings improved their tribological performance. This research corroborates that by applying an adequate heat treatment, hardness and wear resistance of Ni-B coatings can be improved significantly.

Keywords: electroless; heat treatment; Ni-B coating; tribological properties.

\section{Resumen}

Los recubrimientos autocatalíticos de níquel-boro son utilizados en diferentes industrias para mejorar las propiedades mecánicas de materiales, como la dureza y la resistencia al desgaste. En esta investigación se evaluaron las propiedades tribológicas de recubrimientos autocatalíticos Ni-B depositados sobre acero al carbono

\footnotetext{
* Centro de Investigación, Innovación y Desarrollo de Materiales -CIDEMAT-, Universidad de Antioquia (Medellín-Antioquia, Colombia). smilena.arias@udea.edu.co.

** Centro de Investigación, Innovación y Desarrollo de Materiales -CIDEMAT-, Universidad de Antioquia (Medellín-Antioquia, Colombia). maryory.gomez@udea.edu.co.

*** Grupo de Investigación Materiales con Impacto -MAT\&MPAC-, Universidad de Medellín (Medellín-Antioquia, Colombia). escorrea@ udem.edu.co.

**** Centro de Investigación, Innovación y Desarrollo de Materiales -CIDEMAT-, Universidad de Antioquia (Medellín-Antioquia, Colombia). felix.echeverria@udea.edu.co.

***** Centro de Investigación, Innovación y Desarrollo de Materiales -CIDEMAT-, Universidad de Antioquia (Medellín-Antioquia, Colombia). juan.castano@udea.edu.co.
} 
AISI/SAE 1018 antes y después de aplicar un tratamiento térmico a $450{ }^{\circ} \mathrm{C}$ durante 1 hora. Adicionalmente, se realizaron ensayos tribológicos por deslizamiento en seco, utilizando una carga de $5 \mathrm{~N}$ y una velocidad de deslizamiento de $0.012 \mathrm{~m} / \mathrm{s}$, en un tribómetro ball-on-disk fabricado por el CIDEMAT de acuerdo con la norma ASTM G99. De acuerdo con la evaluación tribológica, se estableció que el tratamiento térmico aplicado mejora significativamente el rendimiento tribológico de los recubrimientos autocatalíticos Ni-B.

Palabras clave: autocatalítico; propiedades tribológicas; recubrimiento Ni-B; tratamiento térmico.

\section{Resumo}

Os recobrimentos autocatalíticos de níquel-boro são utilizados em diferentes indústrias para melhorar as propriedades mecânicas de materiais, como a dureza e a resistência ao desgaste. Nesta pesquisa avaliaram-se as propriedades tribológicas de recobrimentos autocatalíticos Ni-B depositados sobre aço ao carbono AISI/SAE 1018 antes e depois de aplicar um tratamento térmico a $450{ }^{\circ} \mathrm{C}$ durante 1 hora. Adicionalmente, realizaram-se ensaios tribológicos por deslizamento em seco, utilizando uma carga de $5 \mathrm{~N}$ e uma velocidade de deslizamento de $0.012 \mathrm{~m} / \mathrm{s}$, em um tribômetro ball-on-disk fabricado pelo CIDEMAT de acordo com a norma ASTM G99. De acordo com a avaliação tribológica, estabeleceu-se que o tratamento térmico aplicado melhora significativamente o rendimento tribológico dos recobrimentos autocatalíticos Ni-B.

Palavras chave: autocatalítico; propriedades tribológicas; recobrimento Ni-B; tratamento térmico.

\section{Para citar este artículo:}

S. Arias, M. Gómez, E. Correa, F. Echeverría-Echeverría, and J. G. Castaño, "Effect of heat treatment on the tribological properties of Nickel-Boron electroless coating," Revista Facultad de Ingeniería, vol. 27 (47), pp. 103-110, Jan. 2018. 


\section{INTRODUCTION}

The electroless nickel process is, in general terms, a chemical reduction method characterized by the selective reduction of nickel ions only on the surface of a catalytic substrate immersed in an aqueous solution of metal ion salts and reducing agent, with the subsequent deposition on the initial film, which catalyzes the reduction reaction. For this reason, the term autocatalytic is also used to describe this type of processes [1-3].

The Ni-B electroless coatings remarkably improve the hardness of the substrates on which they are applied, obtaining higher hardness than with other types of coatings [2-8]. However, this property is also affected by the coating boron content, the particles addition, and the applied heat treatments $[2,8,13]$.

In this research, a heat treatment was applied at $450{ }^{\circ} \mathrm{C}$ for 1 hour under argon atmosphere, and its influence on the tribological properties of Ni-B autocatalytic coatings was analyzed. The presence of different phases before and after the heat treatment was evaluated using X-ray diffraction (XRD) analysis. Changes in composition and morphology were observed through glow-discharge optical emission spectroscopy (GDOES) and scanning electron microscopy (SEM). Dry sliding wear tests were carried out by means of a ball-on-disk tribometer. Sliding wear tracks were studied using SEM.

\section{EXPERIMENTAL METHODOLOGY}

\section{A. Preparation of the substrate surface}

Ni-B electroless coating was deposited on carbon steel AISI/SAE 1018 (C 0.173, Si 0.107, Mn 0.627, $\mathrm{Cu} 0.094$, Cr 0.04, Ni 0.037, Mo 0.011, P 0.0098, S 0.006 ) samples of $1.5 \mathrm{~cm}$ in diameter and $3 \mathrm{~mm}$ in thickness. The samples were mechanically abraded with wet No. 80 sandpaper to homogenize the surface; then, they were blasted with $150 \mu \mathrm{m}$ alumina at $60 \mathrm{psi}$ to improve the adherence of the coating; subsequently, they were washed with an ultrasonic bath in ethanol for 10 minutes and dried with hot air steam. Additionally, pickling was carried out with a mixture of hydrochloric acid and hexamethylenetetramine, as a corrosion inhibitor; then, those samples were washed with distilled water and ethanol and dried with hot air steam.

Posteriorly, the samples were transferred into an electroless-plating bath. Plating was conducted in a glass beaker with only two steel samples immersed and $80 \mathrm{~cm}^{3}$ of fresh solution. To guarantee a homogeneous deposition, the samples were hold with a steel wire to immerse them into the electroless solution. Afterwards, the samples were washed with neutral soap and dried with hot air. To determine the mass gain, the samples were weighed before and after coating formation using a Mettler Toledo AB 204 microbalance with an accuracy of $0.1 \mu \mathrm{g}$. The deposition parameters are listed in Table 1.

\section{TABLE 1}

Chemical COMPOSITION AND OPERATING CONDITIONS OF NI- B ELECTROLESS BATH.

\begin{tabular}{|c|c|}
\hline \multicolumn{2}{|c|}{ AMOUNT FOR A LITER [14] } \\
\hline Chemical Composition & $\begin{array}{l}\text { Amount } \\
\text { (For a liter of } \\
\text { solution) }\end{array}$ \\
\hline $\mathrm{NaOH}$ & $110 \mathrm{~g}$ \\
\hline $\mathrm{NiCl}_{2} .6 \mathrm{H}_{2} \mathrm{O}$ & $20 \mathrm{~g}$ \\
\hline $\mathrm{CH}_{4} \mathrm{~N}_{2} \mathrm{~S}$ & $1 \mathrm{~mL}$ \\
\hline $\mathrm{NH}_{4} \mathrm{HF}_{2}$ & $5 \mathrm{~g}$ \\
\hline $\mathrm{C}_{2} \mathrm{H}_{8} \mathrm{~N}_{2}$ & $35 \mathrm{~mL}$ \\
\hline $\mathrm{NaBH}_{4}$ & $0.8 \mathrm{~g}$ \\
\hline \multicolumn{2}{|c|}{ Operating Conditions } \\
\hline pH & 14 \\
\hline Temperature & $80^{\circ} \mathrm{C}$ \\
\hline Deposition Time & hours \\
\hline
\end{tabular}

\section{B. Heat treatment}

The Ni-B electroless coatings were heat-treated at $450{ }^{\circ} \mathrm{C}$ for one hour under argon atmosphere using a Nabertherm P330 controlled atmosphere furnace. Figure 1 depicts the ramps and temperatures of the heat treatment. The initial temperature (Ti) was $25^{\circ} \mathrm{C}$ while the final temperature (Tf) was $450^{\circ} \mathrm{C}$. R1, R2, and R3 correspond to a heating rate of $5^{\circ} \mathrm{C} / \mathrm{min}$ from Ti to Tf, holding during one hour at $\mathrm{Tf}$, and cooling rate from Tf to Ti, respectively (Fig. 1). 


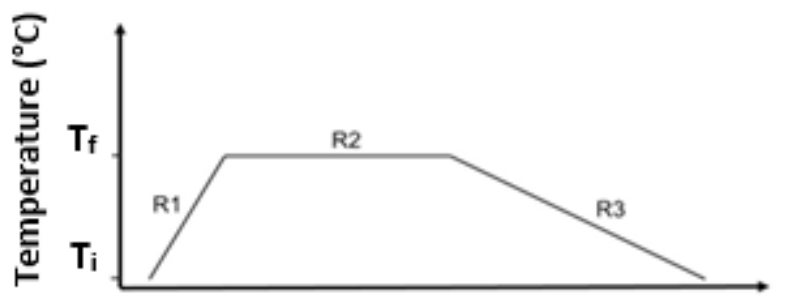

Time (Hours)

Fig. 1. Heating and cooling ramp applied.

\section{Coating characterization}

Surface and cross-sectional images of the coatings were taken in order to assess thickness, composition, and morphology. After the tribological tests, the sliding wear tracks were analyzed using a SEM (JEOL JSM 6490-LV) coupled with a dispersive energy detector for elemental compositional microanalysis (EDS) Oxford IncaPentaFETx-3. The crystalline phases present in the samples before and after heat treatments were analyzed by means of X-ray diffraction (XRD) in a $X$ 'Pert PANalytical Empirean Series II diffractometer with PIXcel 3D detector, in the configuration $\Theta=$ $2 \Theta$, using $\mathrm{Cu}$ radiation, $\mathrm{K} \alpha(0.1541874 \mathrm{~nm})$ model 2012. The data were collected in the $2 \Theta$ range from $10^{\circ}$ to $100^{\circ}$, at a step size of $0.026^{\circ}$, and a time per step of $46.6 \mathrm{~s}$. These data were analyzed through the HighScore Plus software.

The elemental depth profiles were determined using glow-discharge optical emission spectroscopy (GDOES), and the nanohardness was measured in a nanoindentator IBIS Authority of Fischer-Cripps Laboratories. To measure nanohardness, we made indentations at a load of $4 \mathrm{mN}$, in cross sections of the evaluated coatings, reaching a maximum indentation depth of approximately $100 \mathrm{~nm}$.

The tribological tests were carried out according to the ASTM G99: "Standard Test Method for Wear Testing with a Pin-on-Disk Apparatus1" [15], for a load of 5 $\mathrm{N}$ and a speed of $0.012 \mathrm{~m} / \mathrm{s}$, using a $6 \mathrm{~mm}$ diameter alumina counterface describing a $2 \mathrm{~mm}$ diameter wear track on the sample, over a distance of $80 \mathrm{~m}$ and 12732 cycles. The friction coefficient $(\mu)$ was registered every $500 \mathrm{~ms}$. Tests were conducted under regulated laboratory atmospheric conditions of $20^{\circ} \mathrm{C} \pm 2{ }^{\circ} \mathrm{C}$ and $50 \% \pm 5 \% \mathrm{RH}$.
Samples and counterfaces were weighed before and after each tribological test in order to determine the mass loss. At the end of each tribological test, the samples and the counterface used were sonicated for 10 minutes in ethanol to determine the precise mass losses; then, wear rate " $\mathrm{K}$ " was calculated according to $(1)$.

$$
K=\Delta P / F L(1)
$$

Where:

$\Delta \mathrm{P}:$ Loss of mass $(\mathrm{kg})$

F: Applied load (N)

L: Sliding Distance (m)

\section{RESULTS}

\section{A. Morphology, composition, and structure}

Figure 2 shows the surface and cross-sectional SEM images of the coating without heat treatment (Fig. 1a and $1 \mathrm{~b}$ ), and after heat treatment at $450{ }^{\circ} \mathrm{C}$ for one hour (Fig. 1c and 1d). The coatings surface is wavy, reflecting the nodular morphology characteristic of electroless Ni-B coatings, better known as "cauliflower type"; additionally, the formed coating is continuous, uniform, and compact.

Electroless coatings are characterized by following the shape of the coated piece to be coated. The interface is more irregular than the coating surface, with the roughness of the interface generated mainly by the grit blasting of the steel before applying the electroless coating. The adhesion of the coating to the substrate appears to be adequate since no evidence of flaws or defects were observed even after the heat treatments.

After the heat treatment at $450{ }^{\circ} \mathrm{C}$ for one hour (Fig. $1 \mathrm{c}$ and $1 \mathrm{~d}$ ), nodule agglomerations begin to occur, since coating becomes more crystalline. Similarly, the columnar growth of this coating, which was evident in the cross section of the as-deposited coating, becomes more diffuse once the heat treatment was applied, due to the crystallinity achieved in the coating. 

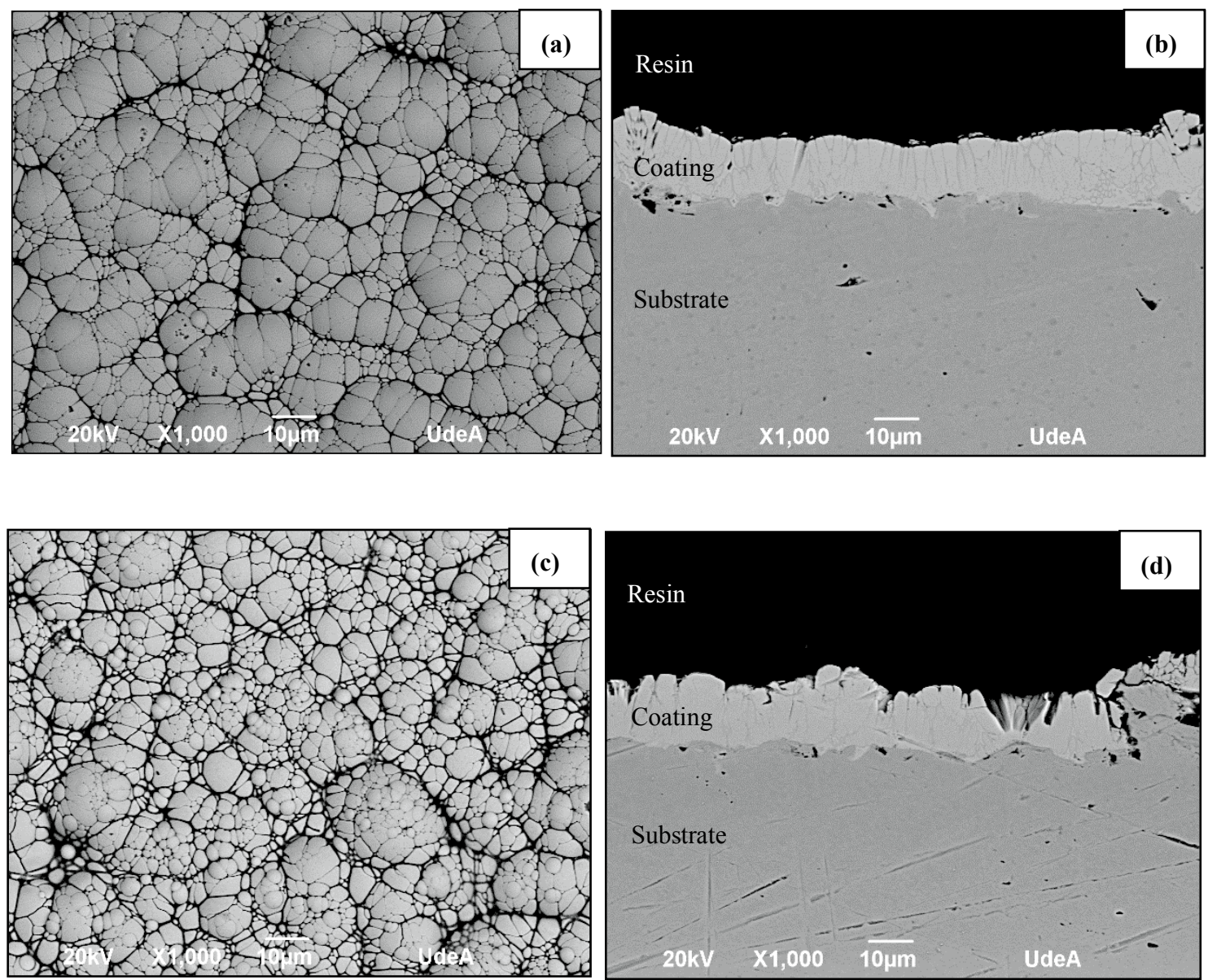

Fig. 2. Morphology and cross section of Ni-B electroless coating without heat treatment ( $a$ and $b$ ), and heat-treated at $450{ }^{\circ} \mathrm{C}$ for one hour (c and d).

Figure 3 shows the variations in nickel, boron, and iron content through the coating, after the GDOES characterization, as-plated condition (Fig. 3a) and after heat treatment at $450{ }^{\circ} \mathrm{C}$ for one hour (Fig. 3b). The nickel and boron content through the as-plated and heat-treated coating was approximately constant. However, after heat treatment, nickel content increased while boron decreased on the coating surface, probably because the boron diffused into the substrate due to its small atomic radius and the increase in temperature. 

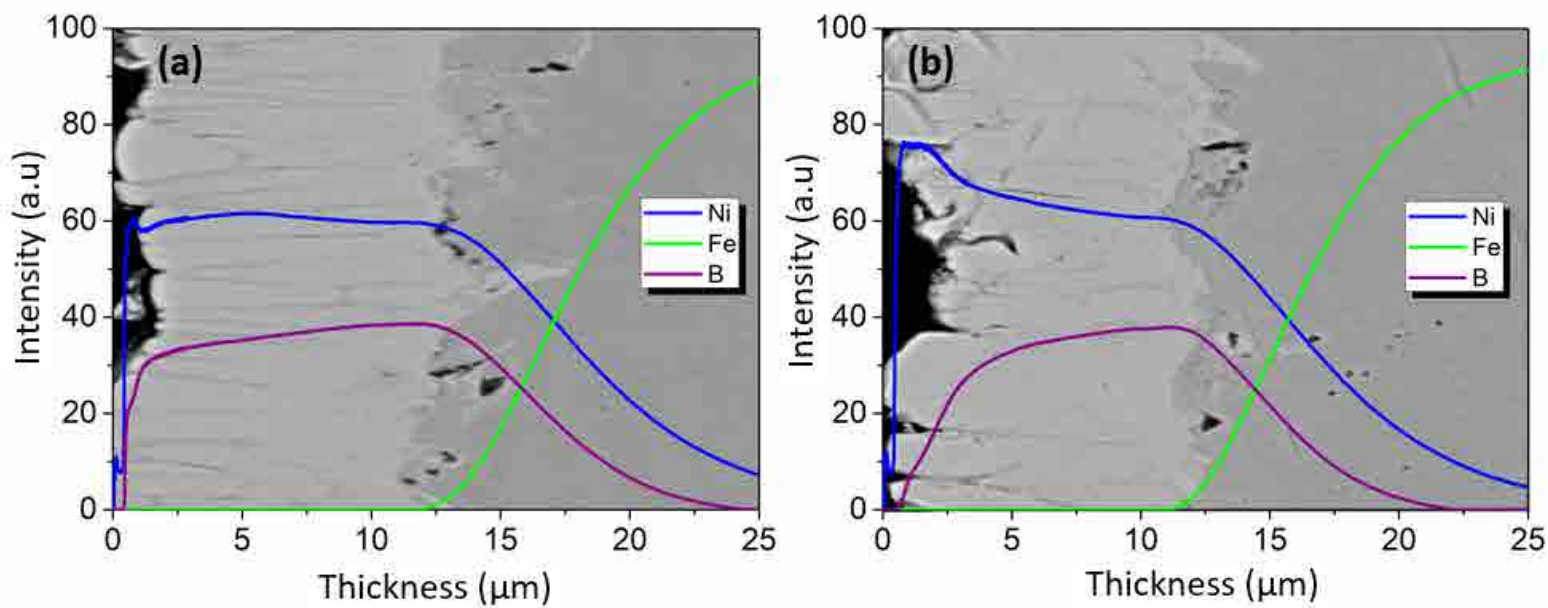

Fig. 3. Optical Emission of Light Discharge Spectra (GDOES) of Ni-B electroless coating without heat treatment (a), and heat-treated at $450^{\circ} \mathrm{C}$ for one hour (b).

Figure 4 illustrates the X-ray diffraction spectra for $\mathrm{Ni}$-B electroless coatings in the as-plated condition and heat-treated at $450{ }^{\circ} \mathrm{C}$ for one hour. For the asdeposited coatings, the main peak of nickel was a broad and low intensity peak, showing the low crystallinity of such coatings. After heat treatment, the diffraction pattern is quite different: the wide peak centered around the main reflection of $\mathrm{Ni}$ ( $\mathrm{fcc}$ ) disappears and is replaced by numerous peaks corresponding to several reflections of $\mathrm{Ni}_{3} \mathrm{~B}$ nickel boride. These peaks are very intense and narrow, which shows the crystalline character of the found phases $[8,16]$.

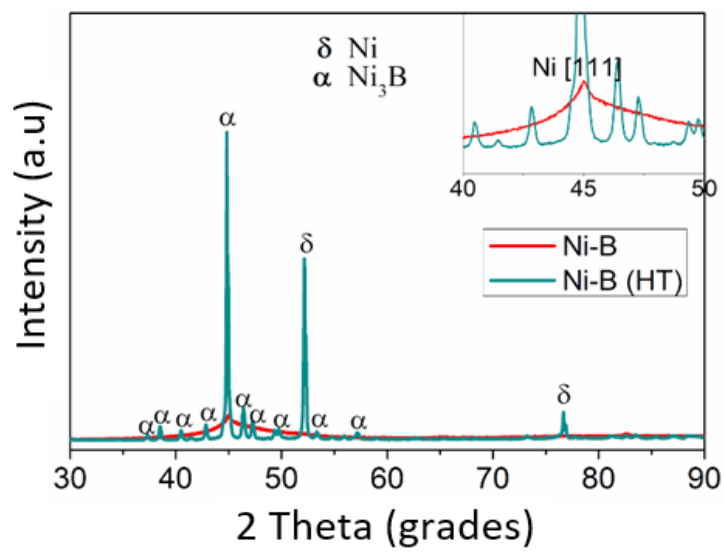

Fig. 4. X-ray diffraction results for electroless Ni-B coatings without heat treatment and heat-treated at 450 ${ }^{\circ} \mathrm{C}$ for one hour.

\section{B. Effect of the heat treatment on the coatings}

The crystalline nickel and nickel boride phases found in the DRX after heat treatment increased the hardness and the elastic modulus, compared to those of the asplated coating. However, the as-deposited coating also improved the hardness and elastic modulus of the steel substrate (Table 2).

\section{TABLe 2}

HARDNESS AND ELASTIC MODULUS FOR THE

SUBSTRATE AND THE EVALUATED COATINGS

\begin{tabular}{|c|c|c|}
\hline Sample & $\begin{array}{c}\text { Hardness } \\
(\mathrm{GPa})\end{array}$ & $\begin{array}{c}\text { Elastic Module } \\
(\mathrm{GPa})\end{array}$ \\
\hline Substrate & 1.3 & 205 \\
\hline Ni-B & $8.60 \pm 3.44$ & $277.54 \pm 19.87$ \\
\hline Ni-B (HT) & $13.38 \pm 1.47$ & $441.48 \pm 67.61$ \\
\hline
\end{tabular}

In the dry sliding tests, the friction coefficient $\mu$ for both the heat-treated and the as-plated Ni-B electroless coatings was stable over the $80 \mathrm{~m}$ test duration, unlike the friction behavior of the evaluated steel substrate (Fig. 5). In addition to the pointed stability, the $\mu$ of the substrate decreased with the deposition of the Ni-B electroless coating; such decrease is more evident after applying the heat treatment.

Reduction of the friction coefficient in $\mathrm{Ni}-\mathrm{B}$ electroless coatings occurs because boron acts as a solid lubricant, reducing wear. Additionally, the cauliflower morphology typical of these coatings reduces the contact area between the parts involved in 
the tribological test by $70 \%$, when the tests are carried out in a dry environment [16-17]. The reduction of the friction coefficient from 0.4 for the substrate to 0.1 for the heat-treated coating is due to the presence of nickel crystalline phases and nickel borides found through the DRX. The wear rate decreased by an order of magnitude with respect to the substrate for as-plated condition, decreasing even more for the heat-treated coatings (Table 3 ). The nickel boride precipitates may have a higher lubricating capacity than the solid Ni-B solution so that the heat-treated coating significantly reduced its friction coefficient.

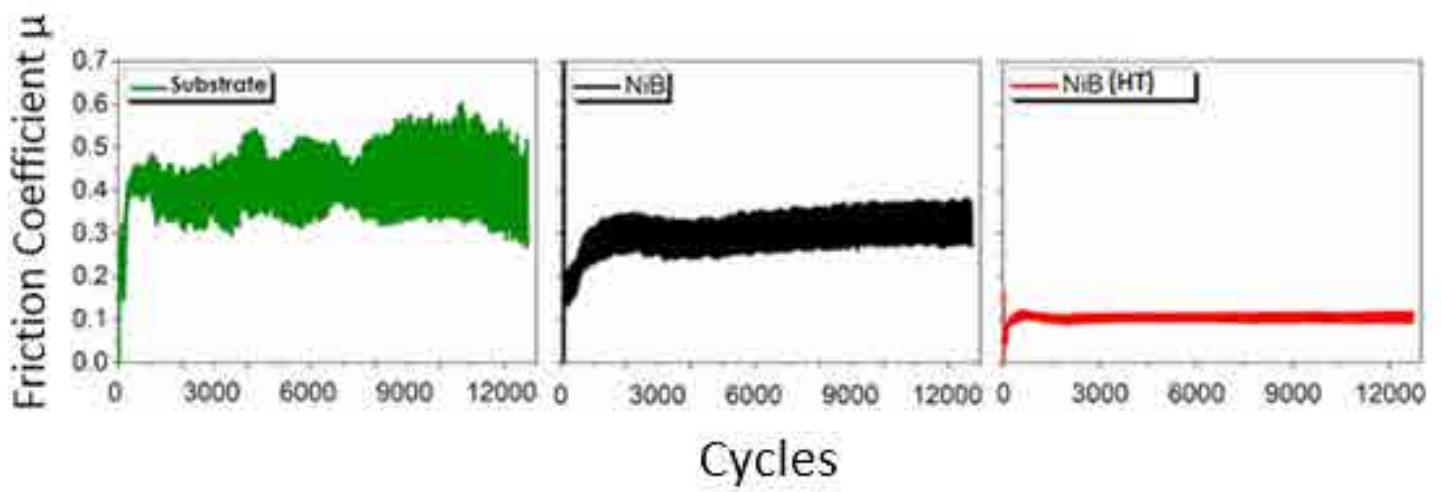

Fig. 5. Friction coefficients in wear test under the condition of $5 \mathrm{~N}$ and $0.012 \mathrm{~m} / \mathrm{s}$ in dry sliding.

TABLE 3

FRICTION COEFFICIENTS AND WEAR RATES FOR THE SUBSTRATE AND Ni-B COATINGS EVALUATED AT 5 $\mathrm{N}$ AND $0.012 \mathrm{M} / \mathrm{s}$

\begin{tabular}{|c|c|c|}
\hline Sample & $\begin{array}{c}\text { Friction } \\
\text { Coefficient } \\
\text { Substrate }\end{array}$ & $\begin{array}{c}\text { Wear Rates }(\mathrm{Kg} / \\
\text { N.m) }\end{array}$ \\
\hline Ni-B & $0.4189 \pm 0.011$ & $1.46 \mathrm{E}-08 \pm 4.52 \mathrm{E}-09$ \\
\hline Ni-B (HT) & $0.3262 \pm 0.0015$ & $1.86 \mathrm{E}-09 \pm 1.64 \mathrm{E}-09$ \\
\hline & $0.2351 \pm 0.0218$ & $2.28 \mathrm{E}-09 \pm 1.57 \mathrm{E}-09$ \\
\hline
\end{tabular}

Smooth wear was evident in both as-plated and heat-treated coatings. Some nodules flattened, while others remained in their original conditions (Fig. 6a). Furthermore, at higher magnifications, it is possible to observe the zones with greater contact between the surface of the coating and the alumina counterface (dark areas), and the more internal sites in the cauliflower structure, where the contact with the counterface is reduced or null (lighter areas) (Fig. $6 b)$.
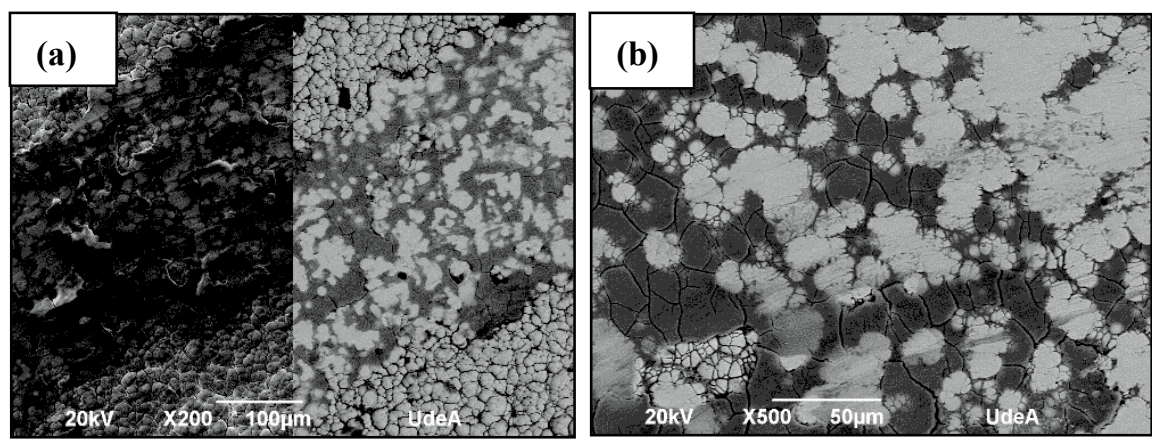

Fig. 6. Wear mechanism observed by SEM for Ni-B electroless coating without heat treatment (a) and heat-treated at $450{ }^{\circ} \mathrm{C}$ for one hour (b) evaluated under the condition of $5 \mathrm{~N}$ and $0.012 \mathrm{~m} / \mathrm{s}$ in dry sliding 


\section{Conclusions}

The Ni-B electroless coatings remarkably improve the hardness and elastic modulus of the AISI/SAE 1018 carbon steel, even more when a heat treatment is applied at $450{ }^{\circ} \mathrm{C}$ for one hour.

The improvement in hardness, elastic modulus, and wear resistance with respect to the substrate after the thermal treatment is due to the precipitation of crystalline phases of $\mathrm{Ni}_{3} \mathrm{~B}$ nickel borides.

Dry sliding wear tests showed that electroless coatings generally have lower friction coefficients compared to the substrate, and that this response is considerably improved by applying heat treatment at $450{ }^{\circ} \mathrm{C}$ for one hour.

The predominant wear mechanism for the evaluated coatings is the flattening of the nodules of the cauliflower structure, which constitutes a mechanism of soft wear, both for the coating without heat treatment and the heat-treated coating.

\section{ACKnowledgment}

The authors express their gratitude to the Committee for the Development of Research (CODI) of the University of Antioquia for funding the project 2014914.

\section{REFERENCES}

[1] P. M. K. K. Hari Krishnan, S. John, K. N. Srinivasan, J. Praveen, and M. Ganesan, "An overall aspect of electroless Ni-P depositions - A review article," Metall. Mater. Trans. A, vol. 37(6), p. 10, 2006. DOI: http://doi.org/10.1007/s11661-006-0134-7.

[2] G. O. Mallory, and J. B. Hajdu, Electroless Plating: Fundamentals and Applications, Noyes Publ. New York, 1990.

[3] B. G. B. Oraon, and G. Majumdar, "Parametric optimization and prediction of electroless $\mathrm{Ni}-\mathrm{B}$ deposition," Mater. Des., vol. 28(7), pp. 21382147, Jan. 2007. DOI: http://doi.org/10.1016/j. matdes.2006.05.017.

[4] F. Delaunois, and P. Lienard, "Heat treatments for electroless nickel-boron plating on aluminium alloys," Surf. Coatings Technol., vol. 160 (2-3), pp. 239-248, Oct. 2002. DOI: http://doi.org/10.1016/ S0257-8972(02)00415-2.

[5] P. Sahoo, and S. K. Das, "Tribology of electroless nickel coatings - A review," Mater. Des., vol. 32
(4), pp. 1760-1775, Apr. 2011. DOI: http://doi. org/10.1016/j.matdes.2010.11.013.

[6] C. Dervos, J. Novakovic, and P. Vassiliou, "Vacuum heat treatment of electroless Ni-B coatings," Mater. Lett., vol. 58 (5), pp. 619-623, Feb. 2004. DOI: http:// doi.org/10.1016/S0167-577X(03)00581-0.

[7] S. Eraslan, and M. Ürgen, "Oxidation behavior of electroless $\mathrm{Ni}-\mathrm{P}, \mathrm{Ni}-\mathrm{B}$ and $\mathrm{Ni}-\mathrm{W}-\mathrm{B}$ coatings deposited on steel substrates," Surf. Coatings Technol., vol. 265, pp. 46-52, Mar. 2015. DOI: http://doi.org/10.1016/j.surfcoat.2015.01.064.

[8] K. Krishnaveni, T. S. N. Sankara Narayanan, and S. K. Seshadri, "Electroless Ni-B coatings: preparation and evaluation of hardness and wear resistance," Surf. Coatings Technol., vol. 190(1), pp. 115-121, Jan. 2005. DOI: http://doi.org/10.1016/j. surfcoat.2004.01.038.

[9] T. S. N. S. Narayanan, K. Krishnaveni, and S. K. Seshadri, "Electroless Ni-P/Ni-B duplex coatings: preparation and evaluation of microhardness, wear and corrosion resistance," Mater. Chem. Phys., vol. 82(3), pp. 771-779, Dec. 2003. DOI: http://doi. org/10.1016/S0254-0584(03)00390-0.

[10] K. Krishnaveni, T. S. N. Sankara Narayanan, and S. K. Seshadri, "Electrodeposited Ni-B coatings: Formation and evaluation of hardness and wear resistance," Mater. Chem. Phys., vol. 99(2-3), pp. 300-308, Oct. 2006. DOI: http://doi.org/10.1016/j. matchemphys.2005.10.028.

[11] D. C. Vitry, and F. Delaunois F., "How heat treatment can give better properties to electroless nickel- boron coatings," La Metallurgia Italiana. Mons, Belgium, p. 6, 2009.

[12] V. Niksefat, and M. Ghorbani, "Mechanical and electrochemical properties of ultrasonic-assisted electroless deposition of $\mathrm{Ni}-\mathrm{B}-\mathrm{TiO}_{2}$ composite coatings," J. Alloys Compd., vol. 633, pp. 127136, Jun. 2015. DOI: http://doi.org/10.1016/j. jallcom.2015.01.250.

[13] Y. Wang, S.-J. Wang, X. Shu, W. Gao, W. Lu, and B. Yan, "Preparation and property of sol-enhanced Ni$\mathrm{B}-\mathrm{TiO}_{2}$ nano-composite coatings," J. Alloys Compd., vol. 617 , pp. 472-478, Dec. 2014. DOI: http://doi. org/10.1016/j.jallcom.2014.08.060.

[14] E. Correa, Direct deposition of electroless NickelBoron coatings on magnesium alloys, Universidad de Antioquia, Medellín, 2013.

[15] ASTM, Standard Test Method for Wear Testing with a Pin-on-Disk Apparatus. United States, 2017, p. 6.

[16] V. Vitry, Electroless nickel-boron deposits: Synthesis, formation and characterization; Effect of heat treatments; Analytical modeling of the structural state, Université de Mons, Bélgica, 2009.

[17] A.-F. Kanta, V. Vitry, and F. Delaunois, "Wear and corrosion resistance behaviours of autocatalytic electroless plating," Journal of Alloys and Compounds, vol. 486 (1-2). pp. L21-L23, Nov. 2009. DOI: http://doi.org/10.1016/j.jallcom.2009.07.038. 